\title{
GREAT BLUE HERON COLONIES IN SASKATCHEWAN IN 1999, A PRELIMINARY INVENTORY
}

LENITA HANSON, Box 294, Clavet, SK SOK OYO and A.R. SMITH, 115 Perimeter Road, Saskatoon, SK S7N 0X4

Standing one metre in height, the Great Blue Heron, locally referred to as the "Blue Crane", is one of Saskatchewan's largest and most conspicuous colonial waterbirds. Yet, populations of this magnificent bird have gone largely unmonitored for the past three decades. Vermeer and Anweiler conducted the most recent provincewide survey of colony size and distribution in the summer of $1970 .^{3}$ They listed 31 active heronries ranging in size from 1 to 75 nests, distributed from the $49^{\text {th }}$ to the $56^{\text {th }}$ parallel. ${ }^{3}$ Six years later, Roney (1976) revisited 13 of these colonies. ${ }^{2}$ With the exception of two colonies found abandoned in the Qu'Appelle valley, his visit revealed no significant changes in colony size or activity from the 1970 survey. Until the summer of 1999, no other substantial initiatives had been undertaken to document colonies of this species in the province.

During the spring and summer of 1999, the authors conducted a preliminary inventory of the size and location of currently and historically active Great Blue Heron colonies in Saskatchewan. For purposes of this article, "historical" or "historically active" sites include those colonies reported to be active in the past but not active at the time of the inventory.

The goals of the study were to: 1) record data and report on any apparent changes in colony distribution and/or colony size since 1970,2$)$ develop a comprehensive database of heron nesting locations across the province, and 3) establish a network of contacts to assist in future population surveys. Data on colonies were obtained by written and oral communication with conservation officers, biologists, naturalists, and landowners, with the exception of two colonies (Middle Lake and Harris Reservoir) personally visited by the authors. The two colonies visited were chosen because of close proximity to other field research projects.

\section{Colony Distribution}

During the course of the study the authors received confirmation of active heron colonies in 32 locations across the province (Table 1), which betters by one the number of active colonies identified in 1970. Distribution across the province in 1999 was similar to 1970 (Figure 1), with the greatest number of colonies located in the Moist Mixed Grassland and Mixed Grassland ecoregions (Table 2). There did, however, appear to be a shift in colonies from the Mid-Boreal Lowland ecoregion, ( 8 colonies in 1970 and 4 in 1999) to the Boreal Transition ecoregion, (4 in 1970 and 8 in 1999).

During our inventory, 16 of 31 sites active in 1970 were reported on, however, only 5 were active (Harris Reservoir, Old Wives Lake, Buffalo Pound Lake, Bone Creek and Anglin Lake). A comparison of nest numbers in these colonies for 1970 and 1999 (Table 3 ) reveals a decline in colony size 
Table 2. Active Great Blue Heron Colonies in Saskatchewan in 1999.

\begin{tabular}{|c|c|c|c|c|c|c|}
\hline Location (Water body) & $\begin{array}{c}\text { Year of First } \\
\text { Report }\end{array}$ & Section & Township & Range & Meridian & $\begin{array}{c}\text { Number of } \\
\text { Nests }\end{array}$ \\
\hline 1 Blackbird Creek & 1996 & 1 & 24 & 30 & W1 & $12^{* *}$ \\
\hline 2 Old Wives Lake (Isle of Bays) & 1913 & 29 & 13 & 29 & W2 & 22 \\
\hline 3 Beacon Hill Comm. Pasture ${ }^{\star}$ & 1999 & - & 16 & 24 & W2 & $3^{* *}$ \\
\hline 4 Caron/Bisant (near Pelican Lake) ${ }^{\star}$ & 1998 & 25 & 17 & 29 & W2 & $11^{\star \star}$ \\
\hline 5 Buffalo Pound Lake (Nicolle Flats) & 1970 & 31 & 18 & 24 & W2 & 5 \\
\hline 6 Rocky Lake (small island in) & 1924 & 36 & 18 & 24 & W2 & 1 \\
\hline 7 Lady Lake* & 1999 & 13 & 35 & 2 & W2 & 6 \\
\hline 8 Middle Lake & 1971 & 26 & 41 & 23 & W2 & 12 \\
\hline 9 Saskatchewan River (Thompson Island) & 1980 & 18 & 49 & 17 & W2 & 15 \\
\hline 10 Saskatchewan River (opposite English Crk.) & 1980 & 13 & 49 & 19 & W2 & 50 \\
\hline 11 Candle Lake & 1971 & 29 & 55 & 22 & W2 & 4 \\
\hline 12 Anglin Lake (Christie Bay) & 1970 & 10 & 55 & 27 & W2 & $* \star \star$ \\
\hline 13 Lac La Ronge PP (Hillis Island) & 1999 & - & 72 & 19 & W2 & 1 \\
\hline 14 Borderland (SE) * & 1999 & 1 & 3 & 1 & W3 & 10 \\
\hline 15 Consul & 1999 & 30 & 4 & 26 & W3 & 3 \\
\hline 16 Harris Reservoir (Fleming Crk.) & 1920 & 5 & 10 & 26 & W3 & 52 \\
\hline 17 Bone Creek (SE of Skull Creek) & 1970 & 4,9 & 11 & 20 & W3 & 15 \\
\hline 18 Highfield Reservoir (Island) ${ }^{*}$ & 1998 & 25 & 15 & 11 & W3 & $10^{* \star}$ \\
\hline 19 Pelican Lake & 1998 & - & 18,19 & 1 & W3 & $7^{* *}$ \\
\hline 20 S. Saskatchewan River (Rd Dr /S. Sask Forks) & 1998 & 36 & 22 & 29 & W3 & 2 \\
\hline 21 Lake Diefenbaker (S. of Elbow) & 1975 & 24 & 24 & 5 & W3 & $20^{* *}$ \\
\hline 22 Eagle Creek & 1998 & 8 & 32 & 12 & W3 & 11 \\
\hline 23 Eagle Creek* & 1999 & 5 & 32 & 12 & W3 & 10 \\
\hline 24 Redberry Lake (New Tern Island) * & 1999 & 11 & 43 & 9 & W3 & 14 \\
\hline 25 Dixon Lake & 1998 & - & 44,45 & 23,24 & W3 & $2^{* *}$ \\
\hline 26 Iroquois Lake & 1982 & 25 & 49 & 8 & W3 & 10 \\
\hline 27 Big Shell Lake & 1982 & 8 & 49 & 8 & W3 & $* \star \star \star$ \\
\hline 28 Kimball Lake* & 1998 & - & 62 & 19 & W3 & 19 \\
\hline 29 Mistohay Lake & 1998 & - & 63 & 21 & W3 & *** \\
\hline 30 Flotten Lake (Island)* & 1999 & - & 65 & 17 & W3 & $20^{* *}$ \\
\hline 31 La Plonge Creek* & 1999 & - & 71 & 11 & W3 & 30 \\
\hline 32 lle a La Crosse (Big Island)* & 1999 & 19 & 74 & 12 & W3 & 10 \\
\hline \multicolumn{7}{|l|}{ * New or previously unreported colonies } \\
\hline \multicolumn{7}{|l|}{ * Data collected in 1998} \\
\hline ***Active but colony size unknown & & & & & & \\
\hline
\end{tabular}

Table 2. Distribution of colonies within Saskatchewan ecoregions in 1970 and 1999

\begin{tabular}{|l|r|r|c}
\hline & \multicolumn{2}{|c|}{$\begin{array}{c}\text { No. of } \\
\text { Colonies }\end{array}$} & $\begin{array}{c}\text { Latitudinal } \\
\text { Range }\end{array}$ \\
Ecoregions & 1970 & 1999 & (Degrees) \\
\hline Selwyn Lake Upland & 0 & 0 & $58-60$ \\
Tazin Lake Upland & 0 & 0 & $59-60$ \\
Athabasca Plain & 0 & 0 & $57-59$ \\
Churchill River Upland & 0 & 1 & $54-58$ \\
Mid-Boreal Upland & 3 & 2 & $52-58$ \\
Mid-Boreal Lowland & 8 & 4 & $53-54$ \\
Boreal Transition & 4 & 8 & $52-54$ \\
Aspen Parkland & 4 & 3 & $49-54$ \\
Moist Mixed Grass & 5 & 7 & $49-53$ \\
Mixed Grass & 5 & 5 & $49-52$ \\
Cypress Upland & 2 & 2 & $49-50$ \\
\hline
\end{tabular}

Table 3. Comparison of great Blue Heron Colonies Active in Saskatchewan in 1970 and 1999

\begin{tabular}{|l|c|c}
\hline Location & $\begin{array}{c}\text { No. of } \\
\text { Nests } \\
1970\end{array}$ & $\begin{array}{c}\text { No. of } \\
\text { Nests } \\
1999\end{array}$ \\
\hline $\begin{array}{l}\text { 1 Buffalo Pound } \\
\text { Lake }\end{array}$ & 65 & 5 \\
2 Harris Reservoir & 65 & 52 \\
3 Anglin Lake & 40 & $*$ \\
4 Old Wives Lake & 5 & 22 \\
5 Bone Creek & 50 & 15 \\
\hline *Active but colony \\
size unknown
\end{tabular}


Figure 1. Locations of active Great Blue Heron colonies in Saskatchewan in 1970 and 1999

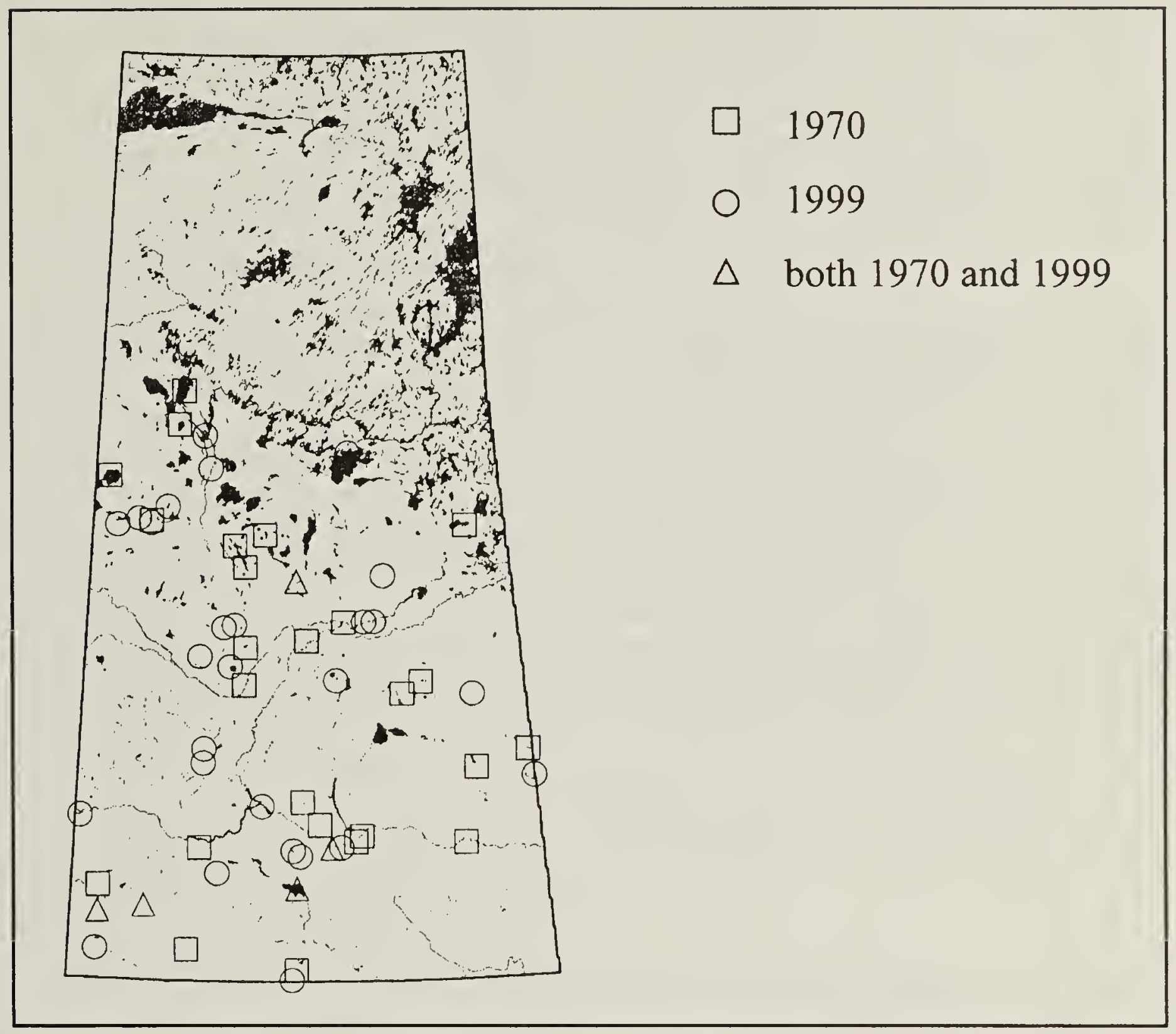

in 3 of the 5 sites. Without more intensive surveys, it would be difficult to determine if these changes are reflections of a population decline or merely evidence of a very mobile, adaptive species.

Thirteen previously unreported colonies (noted by a single asterisk in Table 1) were added to a growing database of 32 current and 143 historical nesting sites. Of particular interest was a single nest heronry located on Hillis Island in Lac La Ronge. This is the first Blue Heron breeding record for the Lac La Ronge area and for the Churchill River Upland ecoregion (Table 2), as well as a rare report of solitary breeding.

\section{Colony Size}

The most important reason for conducting this inventory was to determine the size and trends of the heron breeding population. A trend analysis of Breeding Bird Survey results suggested that between 1966 and 1996 the Great Blue Heron population in Canada increased by $1.9 \%(P>0.05)$ per year. In contrast, the population in Saskatchewan as well as the Prairie Provinces is estimated to have decreased by as much as $6.8 \%$ ( $P$ $>0.05)$ and $5.3 \%(P>0.05)$ per year, respectively. ${ }^{1}$ Nest numbers from the authors' preliminary inventory also indicate a declining population. In 1999, identified heronries were composed of 1 to 52 nests with a mean of 10.9 nests 
per colony. This is significantly lower ( $P$ $<0.01$ ) than the 1 to 75 nests with a mean of 26.8 nests per colony observed in 1970 by Vermeer and Anweiler. ${ }^{3}$ Put another way, only 387 nests in 29 active colonies were reported in 1999, a decrease of more than $50 \%$ from the 830 nests in 31 colonies observed by Vermeer and Anweiler. ${ }^{3}$

Although these numbers are alarming, it is unclear whether they represent a real decrease in the total number of nesting pairs across the province or a stable, but more widely dispersed population (more colonies in 1999 than 1970 but with fewer nesting pairs). This question can only be answered when data on colony size from uncensused colonies as well as data from presently unidentified colonies are recorded. Until such time, the authors caution that the current data set is small and incomplete and therefore represents a minimum population estimate only.

\section{Database}

During the course of the inventory, the database grew to include over 300 nesting records at 175 current and historically active nesting locations. The nesting records include information such as the number of adults, chicks and nests per colony in a given breeding season; other birds nesting with the herons; species of tree in which the heron nests are found; and location of nests (tree tops, or on the ground). Although ground nesting is rare, it has been reported in Saskatchewan. In addition to the nest records, the database contains information concerning colony location, disturbances (natural or human), as well as names of colony observers. All of this information is instrumental in reaching a better understanding of the population patterns and breeding strategies exhibited by this species.

\section{Contacts}

The final goal of this study was to establish a network of individuals that could be contacted each year to report on the status of colonies in their region. At the conclusion of the inventory, the list of reporters and observers in the database had grown tenfold. It is hoped that these individuals will continue to provide information and that others not yet contacted will pass on any knowledge they may have about the colonies listed in Table 1 and/or currently unidentified colonies. The authors would also appreciate any information regarding colonies that are no longer active, such as years the colony was active, year of extinction, reasons for extinction, and, if known, coordinates of the colony's new location. With this kind of help, the most complete and up to date information can be maintained on past and presently active colonies.

In 1978, Roney warned that increased human activities on Saskatchewan lakes and rivers could threaten the success of the Great Blue Heron population. $^{2}$ Sadly, Roney may have been correct, as this inventory has revealed the recent loss of several prosperous colonies, including those on Horseshoe Lake, Marean Lake, Madge Lake and along the Qu'Appelle River. One conservation officer suggested that the loss in his region was related to increased human activities including boating, fishing, and cabin building near these colonies.

The results of the inventory highlight the need for a regular and comprehensive population census. At a minimum, an exhaustive survey should be conducted within the next two years to direct the course of future conservation initiatives. It is hoped that these preliminary results can serve as a stepping stone to better understanding and stewardship of 
Saskatchewan Great Blue Heron populations. If we wish to retain this bird as a member of our avifauna, more effort must be put into monitoring their populations as well as protecting their nesting and feeding grounds from human disturbance.

\section{Acknowledgments}

Without the time and efforts of the following individuals and organizations, the goals of this inventory would not have been realized: Rhys Beaulieu, Nicole Bertrand, Gord Burrows, Warner Carlson, Chris Clark, Mark Cornderund, Ken Costley, Stewart Daia, Alan Debusschure, Chuck Deschamps, Dwight Dobson, Greg Fenty, Marcel Ferland, Mike Flodell, Brenda Flood, Dan Frandsen, Richard Friday, Debbie Greening, Marty Halpape, Wayne Harris, Rich Hidlebrandt, Paul Hopkins, Stuart Houston, Jack Howard, Brian Johns, Greg Johnson, Jeff Keith, Peter Kingsmill, Sean Krichkowski, Brad Mason, Ken Messner, Don Mclnnes, Jim Oliver, Dean Olsen, Joe Ottenbreit, Mark
Oulette, Jeanette Pepper, Bob Plaster, Darryl Robson, Keith Roney, Frank Roy, Michael Paschke, Fred Selsey, Mary Ann Scanell, Arnie Schmidt, Rick Shussel, Larry Slater, Darryl Stan, Jesse Stothers, Phil Taylor, Michael Tether, Robert Wapple, Mark Wayland, Don Weidl, Alan Winarsky, Kerry Wrishko, Jenifer Yantz, and The Kelsey Ecological Society.

1. Downes, C.M., B.T. Collins and B. P. Mcbride. 1999. The Canadian Breeding Bird Survey 1966-1999. National Wildlife Research Centre. Canadian Wildlife Service, Hull, Quebec.

2. Roney, K. 1978. Pelicans, cormorants and Great Blue Herons in Saskatchewan in 1976. Blue Jay 36 (1):28-36.

3. Vermeer, K. and G. Anweiler. 1970. Great Blue Heron colonies in Saskatchewan in 1970. Blue Jay 28 (4):158-161.

\section{INFORMATION NEEDED ON GREAT BLUE HERON COLONIES IN SK}

Although our many contributors were able to provide a great deal of information, many questions remain unanswered. As such, the authors would greatly appreciate hearing from anyone who has current or historical information pertaining to Great Blue Heron nesting activities in Saskatchewan. You may contact us at :
A.R. Smith
115 Perimeter Road
Saskatoon, SK
S7N OX4
Phone (306) 975-4091
Fax (306) 975-4089

Lenita Hanson

Box 294

Clavet, SK

SOKOYO

Phone (306) 382-3120 